Dragica Jojić1, Jelica Predojević-Samardžić1, Gordana Guzijan²,

\section{Immune Hydrops Fetalis}

\begin{abstract}
Hydrops fetalis is a serious condition indicating a bad prognosis of affected fetuses. Incidence of immune hydropsfetalis is significantly decreasing, whereas more and more non-immune hydropsfetalisis are identified. We described a case of the most difficult manifestation of hemolytic disease of a newborn due to rhesus incompatibility. Immune hydrops fetalis occurred due to inadequate immune prophylaxis. While treating the newborn, we applied exchange transfusion, additional transfusion and immunoglobulin therapy. With sensitized pregnant patients, it is necessary to regularly monitor the condition of fetus and titer of mother's antibodies. Considering a difficulty of affected fetuses' disease, it is necessary to strengthen preventive measures by application of rhesus immunoglobulin with affected Rh negative mothers.
\end{abstract}

Key words: hydrops fetalis, RhD alloimmunization, exchange transfusion

\author{
${ }^{1}$ Clinic of Pediatric Surgery, Univer- \\ sity Hospital Clinical Centre Banja \\ Luka \\ 2 Institute for Transfusion Medicine \\ of the Republic of Srpska, \\ Banja Luka, BiH
}

\author{
Contact address: \\ Dragica Jojić \\ 12 beba, 78000 Banja Luka, the \\ Republic of Srpska, Bosnia and \\ Herzegovina \\ Clinic of Pediatric Surgery, \\ University Hospital Clinical Centre \\ Banja Luka \\ +38765465620; +38751342408 \\ e-mail:dragajojic@gmail.com
}

\section{Introduction}

Hydrops fetalis is the excessive accumulation of fluid in two or more fetal tissues, which results in gross edema, occurrence of ascites, pleural and pericardial effusions. This serious clinical condition could lead to fetal death and significant neonatal mortality. In etiology, it has been divided into immune ${ }^{1}$ and non-immune hydrops fetalis, ${ }^{2}$ it occurs in 1:300o live borns. Tendency of decreasing immune hydrops fetalis incidence is present, and it occurs in 10-20\% cases. The most often cause is hemolytic disease of fetus/ neonates (HDFN) defined by Rh(D) alloimmunization. ${ }^{3}$ IgG anti-D antibodies in blood are created with $\mathrm{Rh}(\mathrm{D})$ negative pregnant patient and, afterwards, these transfer to circulation of $\mathrm{Rh}(\mathrm{D})$ positive fetus, they are absorbed to $\mathrm{D}$ positive erythrocytes and destruct them. Process can be so mild that child does not acquire any therapy, but at the same time, it can be so difficult that severe fetal anemia occurs in 20$25 \%$ cases of sick fetuses. Anemia is becoming more serious in spite of extramedullary erythropoiesis, gross edema develops, hypoproteinemia, amount of body water increases, which accumulates in extra cellular tissues region and serous cavities ${ }^{4}$ and circulating anti-erythrocyte antibodies could be identified. Newborn with immune hydrops fetalis has clinical features of a difficult patient with anasarca, as- cites, serious cardio-pulmonic distress, heart insufficiency, perinatal asphyxia, anemia, hyperbilirubinemia, hypoalbuminemia, difficult water-electrolyte disorder, hemorrhagic syndrome, hypotension and acute renal insufficiency. ${ }^{5}$ The treatment is complex; a significant number of newborns are pre-term children requiring respiratory support. There are several guidelines for treating hyperbilirubinemia, intensified photo therapy, exchange transfusion (EST). ${ }^{6}$ Exchange transfusion is used for removing bilirubin and antibodies (IgG anti - D), hypoxia is corrected, numerous metabolic disorders are regulated. There are different techniques of performing the EST. The most often is a common volumetric one with exchange of two blood volumes of $\mathrm{Rh}$ negative appropriate blood type. There is less number of newborns which acquire EST, and the process itself is related to significant morbidity and mortality. ${ }^{7}$ Recently, immunoglobulins are used in the therapy of immune hydrops fetalis and they are administered right after the birth, and hence significantly decrease the risk of developing severe hyperbilirubinemia and need for the EST and additional transfusions . 8

Course and outcome of Rh(D) alloimmunizated pregnancies is uncertain although prophylaxis, possibilities for 
antenatal therapy, intrauterine intravascular transfusion ${ }^{9}$ and postnatal therapy, EST and additional transfusions are applied. Due to this, the most effective preventive measure is administration of rhesus immunoglobulin to $\mathrm{Rh}$ negative women after giving birth, with the risk of RhD sensitization. In our circumstances, $\mathrm{Rh}(\mathrm{D})$ alloimmunization is still very rare.

\section{Case Report}

A male newborn was admitted to the Medical Intensive Care Unit of the Clinic of Pediatric Surgery ,University Hospital Clinical Centre Banja Luka after being taken care of, due to hydrops fetalis, in the delivery room of the Clinic of Gynecology and Obstetrics.

The newborn was the fifth child out of fifth pregnancy of a 30-year-old mother. Pregnancy was supervised due to Rh alloimmunization. Mother's blood type was $\mathrm{B}, \mathrm{RhD}$ negative. The four older children had type $\mathrm{B}, \mathrm{RhD}$ positive and were healthy children. Mother was administered rhesus immunoglobulin after the $1^{\text {st }}, 3^{\text {rd }}$ and $4^{\text {th }}$ pregnancy, but not after the $2^{\text {nd }}$ one. In the fourth pregnancy, sensitization occurred just about the due date, the newborn developed hyperbilirubinemia, which required application of photo therapy. During this pregnancy, titer increase was registered in direct Coombs test (1:8), ultrasound confirmed the presence of fetal ascites and generalized skin edema. It was a preterm birth, conducted in $35+4$ gestation week by urgent Caesarean section. Newborn was 2,820 g, AS 4/6, reanimated after birth. Newborn requested endotracheal intubation and application of mechanical ventilation due to respiratory distress. At the first examination, gross skin edema was present and abdomen was excessively distended due to ascites. Child's blood type was $\mathrm{O}$, RhD positive, direct antiglobulin test (Coombs test) positive, swing +++ , IgG,$+++ c_{3}$ d negative. Blood results showed hemoglobin $99 \mathrm{~g} / \mathrm{L}$, erythrocytes $2.32 \times 10^{\%} / \mathrm{L}$, reticulocytes $3 \%$, leukocytes $10.76 \times 10^{12} / \mathrm{L}$, platelet cells $128 \times 10^{9} / \mathrm{L}$, total bilirubin $210.1 \mu \mathrm{mol} / \mathrm{L}$, direct bilirubin $15.1 \mu \mathrm{mol} / \mathrm{L}$, total proteins $41.7 \mathrm{~g} / \mathrm{dL}$, albumins $26 \mathrm{~g} / \mathrm{dL}$.

Due to anemia and hyperbilirubinemia, double volume exchange transfusion with fresh blood type $\mathrm{O}, \mathrm{Rh}$ negative was performed at the $7^{\text {th }}$ hour of life. During blood exchange, a cardiac arrest occurred, reanimation was performed with administration of Adrenalin, and cardio respiratory instability was maintained. In the first hours of child's life, high values of bilirubin were registered so intensive continuous photo therapy was applied, which was stopped on the 3 rd day of the child's life due to increase in direct bilirubin. The child was administered with immunoglobulin infusion (1 g/ $\mathrm{kg}$ ). Anemia therapy requested erythrocytes transfusion for three times. Apart from correction of hypoalbuminemia, it was necessary to perform correction of water-electrolyte, acid-base and metabolic disorders. Complications were thrombocytopenia $64 \times 10^{9} / \mathrm{L}$ and infection followed by in- crease of inflammatory parameters, but Acinetobacter was isolated from tracheal aspirate only. Additionally, disease course was complicated by interventricular bleeding, second degree, on both sides, as well as Papileu, which was in a gradual regression. Newborn gave favorable feedback to the applied therapy procedures. The child was discharged on the $24^{\text {th }}$ day of his life. At the control examination, at 2.5 months of life, it had moderate hyper tonus and anemia was maintained aside from correction by ferric preparations.

\section{Discussion}

Hydrops fetalis is an urgent medical state requesting fast ultrasound assessment of the fetus at the referent hospital, early identification of possible causes and treatment strategy. Mortality rate of newborn with hydrops fetalis is high - about50-95\% (2). Bad prognosis is followed by smaller gestational age of the newborn, lower Apgar score, severe acidosis and presence of pericardial effusions. ${ }^{10}$

Improvement of survival and favorable outcome is within application of early prenatal intervention -most often intrauterine intravascular transfusion is applied. ${ }^{11}$ There are numerous causes of hydrops fetalis. Lin and associates, in their recently published paper, studied reasons of hydrops fetalisin 156 cases and determined non-immune anemia in $35.9 \%$ cases, cardiac anomaly in $9.6 \%$ cases, intrauterine infection in $7.1 \%$ cases, twins issues in $6.4 \%$ cases, meconium peritonitis in $5.8 \%$ cases, thorax disease - lungs in $5.1 \%$ cases, chromosome anomalies in $4.5 \%$ casesandimmune anemia in1.9\% cases. ${ }^{12}$

Prevalence of immune hydrops was decreased due to $\mathrm{Rh}(\mathrm{D})$ alloimmunization, but alloimmunization was present due to existence of other antigens related to Rh factor, and some of them led to strong anemia and hydrops fetalis. ${ }^{13}$ Because of this, it was necessary to perform screening of mother's antibodies for all possible combinations related toRh factor.

Immune hydrops fetalis is the most difficult form of hemolytic disease of fetus/neonate and it represents a serious medical and social issue. Considering the fact that sensitization of $\mathrm{Rh}(\mathrm{D})$ incompatible transfusion is very rare nowadays, the modern clinical practice sees $\mathrm{Rh}(\mathrm{D})$ incompatible pregnancy as the biggest problem. Etiology of $\mathrm{Rh}(\mathrm{D})$ alloimmunization origin with pregnant women having previous births or previous abortions is mostly due to failure of administration of immune globulin Rh(D)in postpartal period. Women with already created anti-D antibody become pregnant again. ${ }^{14} \mathrm{Rh}(\mathrm{D})$ alloimmunization could also occur as a consequence of invisible transfer of fetal $\mathrm{Rh}$ positive erythrocyte in mother's circulation in an amount big enough to cause immunization. The problem of $\mathrm{Rh}(\mathrm{D})$ alloimmunization has been described and discussed a lot around the world. There are countries with developed 
health protection where sensitization is not existent any more. ${ }^{15}$ In developing countries, immune hydrops fetalis rate is still high. Amin and associates published that occurrence of immune hydrops is $18.42 \%$, and Rh incompatibility is found as cause in $85.7 \%$ cases. ${ }^{16}$ In the Republic of Srpska, similar to other Balkan countries, alloimmunization is still present and it represents one of significant issues of prenatal control.

It is necessary to run the therapy of basic situation leading to hydrops fetalis, as well as entire symptomatic therapy. Repeated exchange transfusions are more often with preterm neonates than full-term neonates. Numerous complications in performance of the EST are described: from technical problems to occurrence of apnea, cardio-respiratory distress, and rare lethal outcome. ${ }^{17}$ Our patient suffered cardiac arrest in performance of the EST with fast reaction to reanimation. After the EST, mild metabolic acidosis was present, as described in study by Patra and associates. ${ }^{18}$

Prevention and therapy of immune hydrops fetalis demands continuous supervision in antenatal, intrapartal, postpartal and neonatal period. The aim of antenatal supervision with $\mathrm{Rh}(\mathrm{D})$ alloimmunizated pregnant women is precise diagnosis of blood type incompatibility and sensitization, timely start of therapy procedures and choice of optima birth date. ${ }^{16}$

Besides prevention, both here and in the world, eradication of HBFN was not performed due to existence of other antigens related to Rh factor. ${ }^{19}$ It is necessary to create programs for application of $\mathrm{Rh}(\mathrm{D})$ immune globulin at the national level, to define possible immune conditions within, during pregnancy and after giving a birth, due to defining appropriate amount of hyper immune anti-D immune globulin. Optimal way of protection includes application of rhesus immune globulin in three doses: first - three months before birth, second - during birth and third -72 hours after birth. ${ }^{20}$ The usage of rhesus immune globulin with risky $\mathrm{Rh}$ negative mothers has reduced alloimmunization throughout the world.

\section{Conclusion}

We presented a case of immune hydrops fetalis resulted from inadequate immune prophylaxis, which provided conditions for Rh alloimmunization. Course of newborn's disease with immune hydrops fetalis is extremely complicated. Invasive procedures and numerous symptomatic therapies are necessary for treatment. Therefore, prevention is the first, the most important and the most efficient step in therapy.

\section{References}

1. Gautier E, Benachi A, Giovangrandi Y, et al. Fetal RhD genotyping by maternal serum analysis: A two-year experience. Am J Obstet Gynecol 2005; 192:666-9.

2. Sohan K, Carroll SG, De La Fuente S, et al. Analysis of outcome in hydrops fetalis in relation to gestational age at diagnosis, cause and treatment. Acta Obstet Gynecol Scand 2001; 80:726-30.

3. Kenneth JM. Fetal anemia due to non-Rhesus-D red-cell alloimmunization. Seminar in fetal and neonatal medicine 2008;13: 207-14.

4. Abrams ME, Meredith KS, Kinnard P, Clark RH. Hydrops fetalis: a retrospective review of cases reported to a large national database and identification of risk factors associated with death. Pediatrics. 2007;120(1):84-9.

5. Muller-Hansen I, Hackeloer BJ, Kattner E. Pre- and postnatal diagnosis and treatment of hydrops fetalis-an interdisciplinary problem. Z Geburtshilfe Neonatol. 1998; 202(1):2-9.

6. Esfandiarpour B, Ebrahimi H, Karkan MF, Farahmand N, Karambin MM. Neonatal exchange transfusion for hyperbilirubinemia in Guilan (the north province of Iran): a 3-year experience. The Turkish Journal of Pediatrics 2012; 54: 626-63.

7. Murray NA, Roberts IAG. Haemolytic disease of the newborn. Arch Dis. Child. Fetal Neonatal Ed. 2007; 92(2): F83-88.

8. Corvaglia L, Legnani E, Galletti S, Arcuri S, Aceti A and Faldella G. Intravenous immunoglobulin to treat neonatal alloimmune haemolytic disease. The Journal of Maternal-Fetal and Neonatal Medicine, 2012; 25(12): 2782-85.

9. Yalinkaya A, Evsen MS, Celik Y and Sak ME. Intrauterine blood transfusion in immune hydrops fetalis , corrects middle cerebral artery Doppler velocimetry very quickly. Bosn J Basic Med Sci 2012; 12 (1): 37-40.

10. Derderian SC, Jeanty C, Fleck SR, Cheng LS, Peyvandi S, MoonGrady AJ et al. The many faces of hydrops. J Pediatr Surg. 2015;50(1):50-4.

11. Liu CA, Huang HC, Chou YY. Retrospective Analysis of 17 Liveborn Neonates with Hydrops Fetalis.Chang Gung Med J 2002; 25(12):826-31.

12. Lin SM, Wang CH, Zhu XY, Li SL, Lin SM, Fang Q. Clinical study on 156 cases with hydrops fetalis. Zhonghua Fu Chan Ke Za Zhi. 2011;46(12):905-10.

13. Ulm B, Svolba G, Ulm MR et al. Male fetuses are particularly affected by maternal alloimmunization to D antigen. Transfusion. 1999;39(2):169-73.

14. Hughes R, Craig J, Murphy W and Greer I. Causes and clinical consequences of Rhesus (D) hemolytic disease of the newborn: a study of Scottish population, 1985-90. British journal of Obstetrics and Gynecology. 1994; 101: 297-300.

15. Abrams ME, Meredith KS, Kinnard P, Clark RH. Hydrops fetalis: a retrospective review of cases reported to a large national database and identification of risk factors associated with death. Pediatrics. 2007;120(1):84-9.

16. Amini E, Farahani Z, Asbagh PA, Esmaiil T and Borna S. Evaluation of Causes, Frequency and Prognosis of Hydrops Fetalis: A Case- Series Study at a Referral Hospital in Tehran , Iran, Int J Pediatr. 2015; 3(13): 391-5. 
17. Chitty HE, Ziegler N, Savoia H, Doyle1 LW and Fox LM. Neonatal exchange transfusions in the 21st century: A single hospital study. Journal of Paediatrics and Child Health 2013; 49:825-32.

18. Patra K, Storfer-Isser A, Siner B, Moore J, Hack M. Adverse events associated with neonatal exchange transfusion in the 1990s. J. Pediatr. 2004; 144: 626-31.

19. Koelewijn J, de Haas M, Vrijkotte T, van der Schoot C, Bonsel G. Risk factors for RhD immunisation despite antenatal and postnatal anti-D prophylaxis. BJOG 2009;116:1307-14.
20. American College of Obstetricans and Gynecologists. ACOG practice bulletin. Prevention of Rh D alloimmunization. Number 4, May 1999 (replaces educational bulletin Number 147, October 1990). Clinical management guidelines for obstetrician-gynecologists. American College of Obstetrics and Gynecology. Int J Gynaecol Obstet 1999; 66:63-70.

\section{Imuni Hidrops Fetalis}

\section{SAŽETAK}

Hidrops fetalis je ozbiljno stanje koje upućuje na lošu prognozu kod pogođenih fetusa. Incidenca imunog fetalnog hidropsa se značajno smanjuje, dok se sve češće opisuje neimuni fetalni hidrops. Opisali smo slučaj najteže manifestacije hemolitičke bolesti novorođenčeta zbog rhesus inkompatibilije, imuni fetalni hidrops nastao zbog neadekvantne imuno profilakse. U liječenju novorođenčeta primenjena je eksangvinotransfuzija, dodatna transfuzija i terapija sa imunoglobulinima. Kod senzibilisanih trudnica potrebno je učestalo pratiti stanje fetusa i titar majčinih antitela. S obzirom na težinu oboljenja pogođenih fetusa potrebno je pojačati preventivne mjere primjenom rhesus imuno globulina kod pogođenih Rh negativnih majki.

Ključne reči: hidrops fetalis, RhD aloimunizacija, eksangvinotransfuzija 